\title{
ACTG1 Gene
}

National Cancer Institute

\section{Source}

National Cancer Institute. ACT G1 Gene. NCI Thesaurus. Code C150159.

This gene plays a role in cell motility. 